\title{
KESULITAN MEMBACA PEMAHAMAN PESERTA DIDIK DI KELAS IVA SD NEGERI 1 KARANGNANAS
}

\author{
Diyah Ayu Windiasari ${ }^{1}$, Cicih Wiarsih ${ }^{2}$, Yudha Febrianta ${ }^{3}$ \\ 1,2,3 Pendidikan Guru Sekolah Dasar, Universitas Muhammadiyah Purwokerto \\ Correspondence Email: diyahayuwindiasari12@gmail.com
}

Received: June 5, 2020 Revised: June 8, 2020 Accepted: June 11, 2020

\begin{abstract}
ABSTRAK
Tujuan penelitian ini adalah untuk mengetahui faktor penyebab kesulitan membaca pemahaman peserta didik di kelas IVA SD Negeri 1 Karangnanas dan upaya guru dalam mengatasi kesulitan membaca pemahaman peserta didik. Jenis penelitian ini adalah studi kasus. Partisipan dalam penelitian yaitu guru, orang tua peserta didik, dan peserta didik dengan teknik pengumpulan data yang dilakukan yaitu wawancara, observasi, dan dokumentasi. Hasil penelitian menunjukan bahwa faktor yang mempengaruhi kesulitan membaca pemahaman peserta didik di kelas IVA SD Negeri 1 Karangnanas yaitu faktor psikologi (kurangnya perhatian dan motivasi belajar dari orang tua maupun guru), faktor pengetahuan tentang cara membaca (rendahnya kemampuan peserta didik dalam menemukan ide pokok bacaan, menentukan watak tokoh dan membuat kesimpulan dari bacaan), dan faktor latar belakang sosial, ekonomi, dan budaya. Upaya yang sudah dilakukan guru dalam mengatasi kesulitan membaca pemahaman peserta didik yaitu dengan latihan, penugasan dan penggunaan strategi pembelajaran ekspositori dan strategi Know Want to Know - Learned (KWL).
\end{abstract}

Kata Kunci: Kesulitan Membaca Pemahaman, Peserta Didik

\begin{abstract}
The purpose of this study was to determine the factors causing the difficulty of reading comprehension of students in grade IVA SD Negeri 1 Karangnanas and the efforts of the teacher in overcoming the difficulty of reading comprehension of students. This type of research is a case study. Participants in the study were teachers, parents of students, and students with data collection techniques, namely interviews, observation, and documentation. The results of research show the factors that affecting the students' difficulty of reading comprehension were, psychological factors (lack of attention and motivation to learn from parents and teachers), knowledge factors about how to read (low ability of students to find the main idea of reading. Determining the character of the character and making conclusions from the reading), and factors of social, economic, and cultural background. The efforts that made by the teacher in overcoming the difficulty of reading students' understanding are through exercises, assignments and the use of expository learning strategies and Know - Want to Know - Learned (KWL) strategies.
\end{abstract}

Keywords: Difficulty Reading Comprehension, Students 


\section{PENDAHULUAN}

Pendidikan merupakan suatu proses pembelajaran kepada peserta didik untuk mengembangkan kemampuan diri sendiri. Pendidikan di Indonesia dibagi menjadi 3 jenis yaitu formal, informal, dan nonformal. Aslikudin (2015: 42) mengemukakan bahwa pendidikan formal merupakan pendidikan yang terstruktur dan berjenjang yang terdiri atas pendidikan dasar, pendidikan menengah, dan pendidikan tinggi.

Pendidikan di sekolah dasar menuntut peserta didik wajib menguasai keterampilan-keterampilan dasar untuk dapat melanjutkan pada jenjang berikutnya. Keterampilan-keterampilan tersebut adalah keterampilan membaca, keterampilan menulis dan keterampilan berhitung. Ketiga keterampilan tersebut diajarkan sejak di kelas rendah sebagai dasar dari pemerolehan pengetahuan. Keterampilan membaca menjadi tolak ukur dari kemampuan peserta didik untuk belajar. Lailiyah (2015: 16) mengemukakan bahwa keterampilan membaca merupakan keterampilan dasar bagi peserta didik yang harus dikuasai agar dapat mengikuti seluruh kegiatan dalam proses pendidikan dan pembelajaran.

Pengajaran membaca di sekolah dasar dibagi menjadi dua yaitu kelas rendah dan kelas tinggi. Kelas rendah yaitu kelas 1 sampai kelas 3 pengajaran membacanya bersifat mekanis atau sering disebut membaca permulaan, sedangkan kelas tinggi yaitu kelas 4 sampai kelas 6 pengajaran membacanya kelanjutan dari kelas rendah yang biasa disebut dengan membaca pemahaman.

Mengingat pentingnya peran membaca pemahaman di sekolah dasar, maka membaca pemahaman merupakan keterampilan yang penting untuk dimiliki oleh peserta didik sekolah dasar. Abidin (2012: 60), menjelaskan bahwa membaca pemahaman merupakan proses yang dilakukan pembaca secara sungguh-sungguh untuk memperoleh berbagai informasi, pesan, dan makna yang terkandung dalam sebuah bacaan.

Kesulitan membaca pemahaman sering dialami oleh peserta didik yang masih duduk di bangku sekolah. Kesulitan membaca pemahaman didefinisikan sebagai suatu gejala kesulitan dalam mempelajari komponen-komponen kata dan 
kalimat. Ada beberapa faktor yang mempengaruhi kemampuan membaca pemahaman,

Annisa \& Rinaldi (2017: 202) mengungkapkan bahwa faktor-faktor yang mempengaruhi kemampuan membaca pemahaman meliputi pengetahuan yang dimiliki sebelumnya oleh pembaca (pembaca akan menghubungkan pengetahuan yang dimiliki sebelumnya dengan pengetahuan yang baru), struktur teks bacaan, penerapan strategi pembaca dalam memproses bacaan dan peran guru dalam memperluas kemampuan peserta didik untuk memahami teks.

Selain faktor yang mempengaruhi keberhasilan membaca pemahaman secara khusus, terdapat faktor yang mempengaruhi keberhasilan membaca pemahaman secara umum. Rahim (2010: 5) menjelaskan beberapa faktor yang dapat mempengaruhi keberhasilan membaca pemahaman secara umum diantaranya adalah faktor fisiologis dan faktor psikologis. Faktor fisiologis yaitu faktor yang berkaitan dengan kesehatan fisik, sedangkan faktor psikologis mencakup motivasi, minat, dan kematangan sosial, emosi dan penyesuaian diri.

Berdasarkan observasi yang dilakukan di kelas IVA SD Negeri 1 Karangnanas, dari 27 peserta didik, 17 laki-laki dan 10 perempuan, ada tiga peserta didik yang mengalami kesulitan dalam menyimpulkan bacaan, karena peserta didik bingung dalam menentukan kata-kata penting yang dapat digunakan dalam menyimpulkan bacaan.

Berdasarkan permasalahan yang telah diuraikan, maka peneliti tertarik melakukan penelitian untuk mengetahui faktor-faktor penyebab kesulitan membaca pemahaman peserta didik di kelas IVA SD Negeri 1 Karangnanas. Oleh karena itu, peneliti akan melakukan penelitian yang berjudul "Kesulitan Membaca Pemahaman Peserta Didik di kelas IVA SD Negeri 1 Karangnanas”.

\section{METODE PENELITIAN}

Penelitian ini dilaksanakan menggunakan pendekatan kualitatif. Sedangkan jenis penelitian yang digunakan oleh peneliti adalah penelitian studi kasus/case study. Penelitian kualitatif menurut Sukmadinata (2016: 60) adalah suatu penelitian yang ditujukan untuk mendeskripsikan dan menganalisis 
fenomena, peristiwa, aktivitas sosial, sikap, kepercayaan, persepsi, pemikiran orang secara individual atau kelompok.

\section{Tempat dan Waktu Penelitian}

Penelitian kualitatif ini dilaksanakan di kelas IVA SD Negeri 1 Karangnanas Kecamatan Sokaraja Kabupaten Banyumas. Penelitian akan dilaksanakan pada semester genap tahun ajaran 2020/2021 pada bulan Januari 2021.

\section{Partisipan Penelitian}

Partisipan dalam penelitian ini adalah guru kelas IVA SD Negeri 1 Karangnanas, orang tua peserta didik, dan peserta didik. Peneliti hanya meneliti 3 peserta didik yang mengalami kesulitan membaca pemahaman di kelas IVA SD Negeri 1 Karangnanas.

\section{Instrumen dan Pengumpulan Data}

Instrumen penelitian dalam penelitian kualitatif adalah peneliti itu sendiri. Teknik mengumpulkan data yang dilakukan dengan observasi, wawancara dan dokumentasi.

\section{HASIL PENELITIAN DAN PEMBAHASAN}

Permasalahan-permasalahan yang dihadapi oleh peserta didik dalam kemampuan berbahasa diantaranya adalah kemampuan membaca pemahaman. Fakta yang terjadi di sekolah dasar, khusunya di kelas tinggi terdapat kesulitan membaca pemahaman yang beragam. Diantaranya peserta didik sudah bisa membaca akan tetapi kesulitan dalam memahami isi bacaan seperti tidak dapat menentukan ide pokok dalam bacaan, kesulitan membuat kesimpulan dari bacaan dan tidak bisa menjawab pertanyaan dengan jawaban tersirat dalam bacaan, serta kurangnya perhatian serta motivasi dari orang tua.

Hasil wawancara diperoleh informasi bahwa terdapat tiga peserta didik yang mengalami permasalahan dalam kemampuan membaca pemahaman. Hal ini sesuai dengan hasil wawancara dengan Ibu GK-F yang menyatakan bahwa:

"Di kelas IVA terdapat tiga peserta didik yang mengalami kesulitan dalam membaca, seperti PD-A, PD-FAN, PD-ZA. Mereka dalam membaca pemahamannya masih kurang. Kalau mengerjakan soal cerita, tidak bisa 
menjawab soal pertanyaan tentang ide pokok bacaan, dan belum bisa menyimpulkan isi dari bacaan. Intinya belum bisa menjawab soal bacaan yang tersirat maupun tersurat." (Ibu GK-F, 7 Januari 2021)

Ibu GK-F menjelaskan bahwa di kelas IVA terdapat tiga peserta didik yang mengalami kesulitan dalam membaca pemahaman, seperti PD-A, PD-FAN, dan PD-ZA. Ketiga peserta didik tersebut dalam membaca pemahaman masih kurang. Mereka tidak bisa menjawab soal pertanyaan tentang ide pokok bacaan, dan belum bisa menyimpulkan isi dari bacaan.

Berdasarkan pernyataan dari Ibu GK-F, peneliti berusaha untuk mengonfirmasi terhadap ketiga peserta didik tersebut. Seperti yang telah dijelaskan oleh Ibu GK-F, bahwa PD-FAN termasuk salah satu dari ketiga peserta didik tersebut yang mengalami kesulitan membaca pemahaman. Peneliti melakukan penelitian terhadap PD-Fan. Hasil penelitian menunjukkan bahwa PDFAN belum lancar dalam membaca. Saat peneliti melakukan wawancara dengan PD-FAN, peneliti meminta PD-FAN untuk membaca dan mengerjakan soal teks bacaan yang telah peneliti sediakan.

Pada saat PD-FAN membaca, PD-FAN kesulitan dalam membaca teks bacaan tersebut sehingga PD-FAN harus mengeja terlebih dahulu teks bacaan tersebut. Hal tersebut sesuai pernyataan dari PD-FAN, yang menyatakan bahwa:

"Belum. Saya belum lancar membaca. Kalau membaca saya harus mengeja dulu, baru bisa baca kalimatnya." (PD-FAN, 8 Januari 2021)

PD-FAN menyatakan bahwa belum lancar dalam membaca. Saat membaca harus dieja terlebih dahulu, baru bisa membaca kalimat tersebut. Permasalahan yang dihadapi PD-FAN juga didukung dengan pernyataan Ibu OR-FAN selaku orang tua dari PD-FAN yang menyatakan bahwa:

"Belum lancar membaca, masih di eja. Kalau nulis juga kadang kurang lengkap hurufnya. Dari kelas I kalau disuruh belajar susah. Saya harus emosi kalau saya minta dia belajar." (Ibu OR-FAN, 8 Januari 2021)

Ibu OR-FAN menjelaskan bahwa PD-FAN belum lancar dalam membaca, saat membaca PD-FAN harus mengeja kata yang dibacanya terlebih dahulu. Permasalahan tersebut berpengaruh terhadap menulis PD-FAN. Seperti yang telah dijelaskan Ibu OR-FAN bahwa dalam menulis PD-FAN terkadang kurang lengkap hurufnya. 
Amalia, Dian (2018:5) mengemukakan bahwa kesulitan peserta didik dalam belajar membaca permulaan yaitu peserta didik dalam membaca dengan tidak lancar, membaca terbata-bata, pemenggalan kata yang tidak tepat, pengucapan tidak benar, dan membaca cepat tetapi banyak salah. Oleh karena itu, PD-FAN sangat memerlukan bimbingan pengajaran membaca permulaan yang lebih intensif, sehingga dapat mengatasi kesulitan membaca yang dialami oleh PD-FAN.

Penelitian selanjutnya, peneliti melakukan penelitian terhadap PD-A. Hasil penelitian terhadap PD-A yaitu dalam membaca pemahaman masih kurang, PD-A tidak bisa mengerjakan soal-soal terkait menentukan ide pokok bacaan dan membuat kesimpulan dari cerita. Hal itu sesuai dengan pernyataan PD-A, yang menyatakan bahwa:

"Tidak bisa menentukan ide pokok dan membuat kesimpulan dalam cerita." (PD-A, 9 Januari 2021)

PD-A menyatakan bahwa dalam membaca pemahaman, masih kesulitan menentukan ide pokok bacaan dan membuat kesimpulan cerita/bacaan. Disaat melakukan penelitian terhadap PD-A, peneliti meminta PD-A untuk membaca dan mengerjakan soal teks bacaan yang telah peneliti sediakan. Peneliti mendapatkan hasil bahwa PD-A lancar dalam membaca, akan tetapi masih kesulitan dalam menentukan ide pokok dan membuat kesimpulan dari teks bacaan tersebut.

Kesulitan yang dialami PD-A juga didukung oleh pernyataan PD-ZA yang menyatakan bahwa:

"Sulit menentukan watak tokoh dalam cerita, apalagi membuat kesimpulan dari cerita." (PD-ZA, 11 Januari 2021)

PD-ZA menjelaskan bahwa PD-ZA sulit dalam menentukan watak tokoh dan menentukan amanat yang terkandung dalam teks cerita yang dibacanya. Pada saat peneliti mewawancarai PD-ZA, peneliti juga meminta PD-A untuk membaca dan mengerjakan soal teks bacaan yang telah peneliti sediakan. Hasil pengerjaan soal teks bacaan tersebut, menunjukkan bahwa jawaban dari pertanyaan terkait menentukan watak tokoh dalam bacaan masih salah, dan dalam membuat kesimpulan dari bacaan kurang tepat. 
Berdasarkan kesulitan yang dihadapi kedua peserta didik tersebut sesuai dengan penelitian sebelumnya yang dilakukan oleh Mirasanthi, dkk. (2016: 8) bahwa penelitian tersebut menjelaskan kesulitan peserta didik dalam kemampuan membaca dikarenakan peserta didik bingung dalam menentukan kata-kata penting yang dapat digunakan dalam menyimpulkan sebuah wacana. Di dalam membaca pemahaman peserta didik tidak hanya dituntut untuk memahami isi bacaan saja, tetapi juga harus mampu menganalisis, mengevaluasi, serta mengaitkanya dalam pengalaman-pengalaman dan pengetahuan awal yang telah dimilikinya.

Kurangnya perhatian serta motivasi dari orang tua juga menyebabkan permasalahan dalam membaca pemahaman. Ibu GK-F menjelaskan bahwa ketiga peserta didik tersebut kurang perhatian serta motivasi dari orang tua. Hal tersebut sesuai pernyataan Ibu GK-F bahwa:

"Menurut saya, mereka kurang perhatian dan motivasi dari orang tua. Semenjak meninggalnya ayah PD-A, ibunya PD-A pergi bekerja ke Jakarta, PD-A tinggal dengan neneknya. Begitu juga dengan PD-ZA, setelah ayahnya meninggal, ibunya kerja ke Hongkong dari PD-ZA kecil sampai sekarang belum pernah pulang. PD-ZA juga tinggal dengan neneknya. Keterbatasan kemampuan nenek mereka jadi mereka tidak terkontrol belajarnya. Kalau ayahnya PD-FAN kerja di bengkel. Berangkat kerja pagi sampai sore. Biasanya malamnya buat istirahat. Kalau ibunya PD-FAN sibuk mengurus adiknya." (GK-F, 7 Januari 2020)

Ibu GK-F menjelaskan bahwa ketiga peserta didik tersebut kurang perhatian serta motivasi belajar dari orang tuanya, karena faktor ekonomi yang menyebabkan orang tua mereka sibuk bekerja. Sehingga belajarnya ketiga peserta didik tersebut tidak terkontrol. Pernyataan tersebut didukung oleh pernyataan Ibu OR-A, salah satu orang tua dari ketiga peserta didik tersebut, yang menyatakan bahwa:

"Karena saya sibuk bekerja kayaknya jadi kurang perhatian sama anak, motivasi yang saya berikan juga kurang. Jadi berpengaruh sama kegiatan belajarnya di rumah.” (Ibu OR-A, 9 Januari 2021)

Ibu OR-A menjelaskan bahwa karena kesibukannya dalam bekerja sehingga kurang perhatian serta motivasi kepada peserta didik sehingga berpengaruh terhadap kegiatan belajar peserta didik saat di rumah. Rubin (Rahim, 2010: 20) mengemukakan bahwa salah satu faktor yang sangat penting bagi 
kesuksesan belajar peserta didik ialah motivasi, keinginan, dorongan, dan minat yang terus-menerus untuk mengerjakan suatu pekerjaan. Dengan demikian, orang tua peserta didik bertanggungjawab dalam memotivasi serta memberikan perhatian kepada peserta didik agar selama kegiatan belajar di rumah dapat meningkatkan prestasi peserta didik.

Upaya yang sudah dilakukan guru untuk mengatasi kesulitan membaca pemahaman peserta didik yaitu dengan latihan, penugasan dan penyampaian materi pembelajaran secara bertahap. Hal tersebut sesuai Ibu GK-F yang menyatakan bahwa:

"Sekarang pembelajarannya online, jadi saya mengupayakan agar materi pembelajaran bisa tersampaikan dengan baik. Saat pembelajaran saya memberikan soal latihan, dan setelah selesai pembelajaran biasanya saya memberikan tugas-tugas. Strategi yang saya gunakan itu menggunakan google meet atau zoom. Jadi saya bisa menyampaikan materi secara verbal dan bertahap." (Ibu GK-F, 7 Januari 2021)

Ibu GK-F menjelaskan bahwa dalam pembelajaran Ibu GK-F memberikan soal latihan, dan setelah selesai pembelajaran biasanya memberikan tugas-tugas kepada peserta didik. Ibu GK-F juga menggunakan strategi pembelajaran dengan menggunakan google meet atau zoom agar penyampaian materi pembelajaran dapat tersampaikan secara virtual dan bertahap, sehingga peserta didik memahami materi pembelajaran yang disampaikan. Strategi pembelajaran tersebut dapat dikatakan sebagai strategi pembelajaran ekspositori. Tutik (2019: 16) menjelaskan bahwa strategi pembelajaran ekspositori merupakan strategi pengajaran yang menekankan kepada proses penyampaian materi secara verbal dari seorang guru kepada sekelompok peserta didik dengan maksud agar siswa dapat menguasai materi secara optimal.

Berdasarkan hasil penelitian terdahulu yang dilakukan oleh Lisnaeni (2017: 61) bahwa penggunaan strategi pembelajaran ekspositori efektif dalam meningkatkan hasil belajar peserta didik pada mata pembelajaran Qur'an Hadis di Madrasah Aliyah (MA) Bukit Hidayah Malin. Strategi pembelajaran ekspositoris merupakan bentuk pendekatan yang berorientasi kepada guru. Sebab dalam strategi ini guru memegang peran yang sangat dominan. Sehingga materi pembelajaran yang disampaikan dapat dikuasai peserta didik dengan baik. 
Selain upaya tersebut di atas, Ibu GK-F menggunakan strategi lain dalam proses pembelajaran. Seperti yang diungkapkan oleh Ibu GK-F bahwa:

"Terkadang saya juga menggunakan strategi lain dalam mengajar, tergantung pada materi yang akan saya sampaikan. Jadi tidak semua materi dalam satu tema, saya hanya menggunakan satu strategi saja. Biasanya saya menggunakan strategi untuk membuat peserta didik aktif dulu sebelum masuk ke materi pembelajaran. Saya mengarahkan dan memfokuskan peserta didik agar fokus ke materi kan akan dipelajari dengan bertanya kepada peserta didik tentang topik yang akan dibahas." (Ibu GK-F, 7 Januari 2021)

Ibu GK-F mengungkapkan bahwa tidak hanya menggunakan satu strategi saja dalam proses mengajar. Strategi tersebut tergantung pada materi yang akan disampaikan. Biasanya sebelum kegiatan belajar mengajar dimulai. GK-F mengarahkan dan memfokuskan peserta didik agar focus ke materi yang akan dipelajari dengan bertanya terlebih dahulu mengenai topik yang akan dibahas. Strategi yang digunakan GK-F dapat dikatakan sebagai strategi Know - Want to Know - Learned (KWL). Abidin (2012: 87) mengungkapkan bahwa strategi Know - Want to Know - Learned (KWL) sangat berguna untuk membiasakan siswa menentukan tujuan membaca sebelum membaca dan mengaktifkan siswa sebelum, saat, dan sesudah membaca.

Berdasarkan penelitian sebelumnya yang dilakukan oleh Isnaini (2015: 100) bahwa penggunaan strategi Know - Want to Know - Learned (KWL) terbukti efektif digunakan dalam pembelajaran memahami teks ulasan siswa kelas VIII SMP Negeri 15 Yogyakarta. Penggunaan strategi Know - Want to Know Learned (KWL) tersebut mampu menghidupkan latar belakang pengetahuan dan minat peserta didik untuk dapat memahami isi teks.

\section{SIMPULAN DAN SARAN}

\section{Simpulan}

Berdasarkan dari hasil penelitian yang dilakukan terhadap guru, orang tua peserta didik, dan tiga peserta didik dapat disimpulkan bahwa faktor yang mempengaruhi kesulitan membaca pemahaman peserta didik di kelas IVA SD Negeri 1 Karangnanas dipengaruhi oleh faktor psikologi (kurangnya perhatian dan 
motivasi belajar dari orang tua maupun guru mempengaruhi kegiatan peserta didik selama di rumah), faktor pengetahuan tentang cara membaca (kemampuan peserta didik yang rendah dalam menemukan ide pokok bacaan, menentukan watak tokoh dan membuat kesimpulan dari bacaan), dan faktor latar belakang sosial, ekonomi, dan budaya (keterbatasan ekonomi keluarga peserta didik, membuat orang tua peserta didik harus bekerja untuk mencukupi kebutuhan hidup keluarga. Sehingga waktu bersama dengan peserta didik kurang optimal).

Upaya yang sudah dilakukan guru dalam mengatasi kesulitan membaca pemahaman peserta didik di kelas IVA SD Negeri 1 Karangnanas yaitu dengan latihan, penugasan dan penggunaan strategi pembelajaran ekspositori dan strategi Know - Want to Know - Learned (KWL).

\section{DAFTAR PUSTAKA}

Abidin, Y. (2012). Pembelajaran Membaca Berbasis Pendidikan Karakter. Bandung: Refika Aditama

Amalia, Dian. (2018). Upaya Meningkatkan Hasil Belajar Siswa Melalui Strategi Contextual Teaching And Learning (CTL) Pada Pembelajaran Ipa Materi Bagian-Bagian Pada Tumbuhan Di Kelas Iv Mis Parmiyatu Wassa'adah Tembung Percut Sei Tua

Annisa, W \& Rinaldi, R. (2017). Kemampuan Membaca Pemahaman dengan Strategi The Cognitive Academi Language Learning Approach (CALLA) Berbasis Kearifan Lokal Peserta Didik Kelas VII SMP Negeri 18 Padang. Jurnal Puitika, 11(1), 200-206

Aslikudin, N. (2015). Persepsi Masyarakat Tentang Pentingnya Pendidikan Formal Implikasinya Dalam Sikap Kedewasaan Anak Di Dusun Semoto, Desa Sugihmas, Kecamatan Grabag, Kabupaten Magelang

Isnaini, M. L. (2015). Keefektifan Strategi K-W-L (Know-What to KnowLearning) Dalam Pembelajaran Memahami Teks Ulasan Pada Siswa Kelas VIII SMP Negeri 15 Yogyakarta

Lailiyah, M. N. 2015. Penggunaan Media Kantong Pintar Bahasa Indonesia untuk Meningkatkan Keterampilan Membaca Puisi pada Pelajaran Bahasa Indonesia Peserta didik Kelas V MI Darus Salam Gresik

Lisnaeni. (2017). Efektivitas Strategi Pembelajaran Ekspositori Dalam Meningkatkan Hasil Belajar Qur'an Hadis Pada Peserta Didik Kelas X Madrasah Aliyah Bukit Hidayah Malino 
Mirasanthi, dkk. (2016). Analisis Kemampuan Peserta didik Dalam Membaca Pemahaman Pada Wacana Narasi Kelas V SD Negeri 1 Penarukan. eJournal PGSD Universitas Pendidikan Ganesha Jurusan PGS. 4(1),1-10

Rahim, F. (2010). Pengajaran Membaca di Sekolah Dasar. Jakarat: PT Bumi Aksara

Sukmadinata. (2016). Metode Penelitian Pendidikan. Bandung: Remaja Rosdakarya

Tutik, W. (2019). Strategi Guru Dalam Mengatasi Kesulitan Membaca Pada Kelas Rendah Di DSN Nglutung 1 Sendang Tulungagung 